\title{
NIE TYLKO „GENERAŁ MRÓZ” WPŁYW CZYNNIKÓW POGODOWYCH NA PRZEBIEG KAMPANII ROSYJSKIEJ NAPOLEONA NA WYBRANYCH PRZYKŁADACH
}

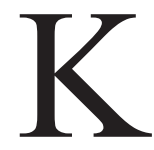

lęska Wielkiej Armii Napoleona Bonaparte w Rosji do dziś pozostaje jednym z najbardziej znanych przykładów wpływu czynników pogodoniemniej warto zauważyć, że niesprzyjające warunki atmosferyczne towarzyszyły obu stronom konfliktu nie tylko zimą, ale też pojawiały się pod różnymi postaciami już od pierwszych dni walk.

Celem niniejszego artykułu jest próba przedstawienia, na wybranych przykładach, wpływu warunków pogodowych, w szczególności opadów atmosferycznych (deszczu, śniegu) oraz temperatury, na przebieg działań wojennych, w tym mobilność wojsk, zdrowie i kondycję żołnierzy oraz tok samych starć, a także próba odpowiedzi na pytanie, czy pogoda odegrała kluczową rolę w klęsce wojsk napoleońskich w Rosji.

Na początek warto pokrótce przedstawić warunki klimatyczne Rosji i czynniki wpływające na ich kształt $\mathrm{w}$ trakcie kampanii roku 1812. Z racji znacznego obszaru terytorium państwa rosyjskiego, zarówno w XIX w. jak i obecnie, w jego obrębie występują zróżnicowane strefy klimatyczne - od umiarkowanego, poprzez kontynentalny, kończąc na subarktycznym. W interesującej nas, zachodniej części państwa rosyjskiego z początku XIX w., którego granice sięgały bardziej za zachód niż obecnie, występuje po części klimat umiarkowany, a przede wszystkim 
kontynentalny. Ten drugi, nie wdając się w szczegóły, odznacza się ciepłymi i suchymi latami, krótkimi jesieniami oraz dość długimi, mroźnymi zimami, którym towarzyszą intensywne opady śniegu¹.

Na warunki pogodowe w Rosji na początku XIX w. oddziaływały również ogólnoświatowe czynniki destabilizujące klimat, mające wpływ na powstanie anomalii pogodowych, których opis znajdzie się w dalszej części artykułu. Grupa amerykańskich badaczy (Rosanne D’Arrigo, Rob Wilson i Alexander Tudhope) wiąże te anomalie z licznymi erupcjami wulkanicznymi w strefie tropikalnej - na wyspie Sumbawa w archipelagu Małych Wysp Sundajskich (wulkan Tambora) i wyspie Luzon na Filipinach (wulkan Mayon), do których doszło w latach 18091811, a także na wyspie Saint-Vincent na Karaibach (wulkan Soufrière) z wiosny 1812 r. W wyniku aktywności wulkanicznej do atmosfery dostała się znaczna ilość pyłów i gazów m.in. dwutlenku węgla, związków siarki i metanu. Pyły wulkaniczne, zawieszone $\mathrm{w}$ atmosferze, wstrzymywały dopływ energii słonecznej. Do tego warto odnotować, mające miejsce w latach 1790-1830, tzw. minimum Daltona skutkujące mniejszą aktywnością słońca. Powyższe czynniki prowadziły do powstania anomalii klimatycznych widocznych na półkuli północnej w latach 1811-1813. Były one dostrzegalne w Rosji już przed rozpoczęciem napoleońskiej inwazji. Paradoksalnie zima 1811/1812 była, jak na standardy rosyjskie, dość łagodna - w Petersburgu nie zamarzła rzeka Newa, zaś na zachód od linii Dniepru, czyli na obszarze z bardziej umiarkowanym klimatem, praktycznie nie odnotowano opadów śniegu. Dopiero na początku 1812 r. pojawiły się mrozy, które doprowadziły do opóźnienia się okresu żniw². Niestandardowa jak na warunki rosyjskie pogoda pojawiała się wielokrotnie w przeciągu kampanii roku 1812.

Problemy Wielkiej Armii związane z warunkami pogodowymi rozpoczęły się jeszcze przed rozpoczęciem kampanii - podczas koncentracji wojsk intensywne opady doprowadziły do powstania problemów z poruszaniem się wojsk i taborów po drogach oraz skutkującego tym powstania na nich zatorów. Paraliżowało to przemarsze oddziałów, a także destabilizowało system zaopatrzenia wojsk napoleońskich, który na potrzeby kampanii w Rosji został rozbudowany celem zrekompensowania spodziewanej mniejszej możliwości pozyskiwania żywności na terenie państwa rosyjskiego 3 .

${ }^{1}$ Zgodnie z klasyfikacją Köppena dominującym klimatem we współczesnej Rosji jest Dfb (klimat kontynentalny z ciepłym latem). Szerzej na temat klimatu Rosji [w:] KLIMAT: ROSJA, https://pl.climate-data.org/azja/rosja-136/ [dostęp: 23 IX 2019 r.].

2 R. D'Arrigo, R. Wilson, A. Tudhope, The impact of volcanic forcing on tropical temperatures during the past four centuries, „Nature Geoscience” 2009, no. 2, s. 51-56; Generał Mróz?, https://napoleon.org.pl/forum/viewtopic.php?f=19\&t=65 [dostęp: 23 IX 2019 r.]; A. KonIUCH, Rok bez lata, „Przegląd Pożarniczy” 2014, nr 5, s. 28; A. ZAмoyski, 1812. Wojna z Rosją, Kraków 2008, s. 144.

3 J. Czubaty, Rok wojny, urodzaju i anarchii, „Mówią Wieki. Napoleon rusza na Rosję” 2012, nr specjalny 2, s. 67. 
Jeszcze bardziej pogoda dała o sobie znać tuż po rozpoczęciu kampanii. Stało się tak w wyniku burzy, która rozpoczęła się w nocy $28 / 29$ czerwca $^{4}$ i miała miejsce w pasie około $200 \mathrm{~km}$ od Kowna przez Wilno w stronę rzeki Prypeć. Zdaniem adiutanta Napoleona, Philippe’a Paula de Ségura: „Burza ta dorównywała wielkością naszemu przedsięwzięciu" ${ }^{5}$. Jej destrukcyjny dla armii napoleońskiej charakter był związany w szczególności z towarzyszącym opadom obniżeniem się temperatury (z ponad 30 do kilku ${ }^{\circ} \mathrm{C}$ ), w wyniku czego oprócz deszczu odnotowywano również gradobicia, a nawet opady śniegu ${ }^{6}$. Porucznik francuskiej Gwardii Cesarskiej Jean-Roche Coignet opisał burzę oraz jej konsekwencje w sposób następujący:

Burza okazała się tak gwałtowna, z opadami gradu i śniegu, iż z trudem udało się utrzymać konie - trzeba było je wiązać do kół. Umierałem z zimna; nie mogąc już wytrzymać - otworzyłem jeden z furgonów i ukryłem się w nim. Rano rozpościerał się bolesny dla nas widok! Niedaleko obok nas znajdował się obóz kawalerii i ziemia tam pokryta była padniętymi z zimna zwierzętami. [...] Pozostałe przy życiu konie tak się trzęsły ze zimna, iż mogły sobie coś złego zrobić, lecz dały się jakoś zaprzęgnąć [...]. Po dotarciu do drogi ujrzeliśmy martwe ciała żołnierzy, który nie przetrwali tej okropnej burzy ${ }^{7}$.

Trwająca przez trzy, a według niektórych źródeł nawet pięć, dni ulewa wpłynęła na dopiero co rozpoczętą kampanię w wielowymiarowy sposób. Po pierwsze, w wyniku wahań temperatur doszło do śmierci wielu koni osłabionych w wyniku intensywnych marszy, a przede wszystkim braku paszy oraz stosowania szkodliwej dla nich diety w postaci mokrej trawy oraz niedojrzałego owsa i jęczmienia powodujących u nich kolkę. Według wyliczeń generalnego intendenta Wielkiej Armii gen. Mathieu Dumasa w ciągu pierwszych kilku dni wojny armia napoleońska straciła około 10 tys. koni, choć pojawiają się i szacunki mówiące o stracie do 40 tys. zwierząt. Ubytki dotknęły zarówno jednostek artylerii, których większość straciła nawet do $25 \%$ koni pociągowych ${ }^{8}$, a także taborów i artylerii - według szacunków Abrahama Rosseleta z 1 pułku piechoty szwajcarskiej w samym II Korpusie w tym okresie miało paść około 1,5 tys. koni.

\footnotetext{
${ }^{4}$ Coignet jako datę początkową podaje okolice godziny 15 - 29 czerwca. J.-R. CoIGNET, $W$ imię Cesarza!!! Kajety kapitana Coignet. Z życia żolnierskiego napoleońskiego gwardzisty, tłum. R.J. KoMOROWSKI, Oświęcim 2014, s. 149.

${ }^{5}$ P.P. DE SÉGUR, Wspomnienia F.P. de Ségura adiutanta Napoleona, tłum. E. LeszczyŃsKa, Warszawa 1967, s. 33.

${ }^{6}$ L.A. Picard, Kawaleria w wojnach Rewolucji i Cesarstwa 1792-1815, t. II, Oświęcim 2014, s. 63; A. ZамоYsкi, op. cit., s. 161.

7 J.-R. CoIGnet, op. cit., s. 149.

${ }^{8}$ Stratę czwartej części koni odnotował chociażby dowódca artylerii 3 Dywizji Kawalerii Lekkiej płk Charles-Pierre-Lubin Griois.

${ }^{9}$ M. Kukiel, Wojna 1812 roku, t. I, Poznań 1999, s. 301; D. NAwrot, Litwa i Napoleon w 1812 roku, Katowice 2008, s. 185; A. ZAmoyski, op. cit., s. 161.
} 
Przyjmując podaną przez M. Dumasa liczbę 10 tys. padniętych koni, a trzeba też pamiętać o wielu zwierzętach zmęczonych pogodą i dietą, które padły w kolejnych dniach, był to bolesny cios dla Wielkiej Armii, a przede wszystkim jej systemu zaopatrzenia. Według raportów w przededniu kampanii wojska napoleońskie dysponowały ogromną masą $157353 \mathrm{koni}^{10}$. Przytoczone straty, przyjmując minimalne i maksymalne rachunki, sięgają zatem od niecałych $16 \%$ do ponad $39 \%$ stanu wyjściowego. Stawiało to w bardzo trudnej sytuacji system zaopatrzenia, który i tak mógł dostarczyć jedynie połowę potrzebnych dostaw, mimo zgromadzenia przed kampanią ogromnych zapasów znajdujących się w magazynach w Gdańsku, Toruniu i Królewcu ${ }^{11}$, a także dość wysokiego przelicznika liczby koni przypadających na grupę żołnierz (1 koń na 4 żołnierzy). Sytuację dodatkowo komplikowała ograniczona możliwość uzupełniania strat z racji operowania na terytorium przeciwnika. Dlatego też sięgano po lokalne konie polskie (nazywane przez Francuzów cognats) - wytrzymałe, lecz małe, a przez to nieodpowiednie chociażby dla jazdy ${ }^{12}$.

Wracając do skutków burzy, poza końmi śmierć poniosła również pewna grupa żołnierzy - w większości w wyniku wychłodzenia, ale także wskutek uderzeń piorunów - Adam Zamoyski w swojej pracy przytacza pogłoskę o porażeniu trzech grenadierach Starej Gwardii, z kolei śmierć dwóch ludzi i trzech koni w ich wyniku odnotował François Dumonceau z 2 pułku szwoleżerów-lansjerów Gwardii Cesarskiej (holenderskiego) ${ }^{13}$. Widok wielu martwych koni oraz żołnierzy, a także długotrwałe opady wpłynęły negatywnie na morale żołnierzy ${ }^{14}$.

${ }^{10}$ W tej liczbie znajdowało się 107537 koni wierzchowych (68,3\% ogółu) należących do sztabu głównego, świty cesarskiej, oficerów oraz oddziałów kawalerii, zaś pozostałe 49816 (31,7\%) znajdowały się w różnych pociągach, w tym około $27300 \mathrm{w}$ pociągach artylerii oraz jednostkach inżynierskich. Z tej liczby 20750 ciągnęło działa i wozy amunicyjne, dalszych 2550 koni należało do pontonierów, zaś 4000 transportowało armaty pułkowe. Do komunikacji transportu między wielkimi jednostkami i zapleczem przeznaczone było tylko 10500 koni (21\%). Pozostałe zwierzęta przypisano do służb pomocniczych - wozów pułkowych, ambulansów itp. François Houdecek w swoim artykule podaje nieco większą liczbę koni - 169 966, jednakże uwzględnia również jednostki tyłowe (w tym IX i XI Korpus) oraz zakłady kawalerii. Vide: F. Houdecek, La Grande Armée de 1812, organisation à l'entrée en campagne, https://www.academia.edu/9576339/La_Grande_Arm\%C3\%A9e_ de_1812_organisation_\%C3\%A0_lentr\%C3\%A9e_en_campagne [dostęp: 28 IX 2019 r.].

${ }^{11} \mathrm{O}$ niewydolności komunikacji z zapleczem świadczy fakt, że już na tydzień przed kampanią żołnierzom wydawano połowę racji żywnościowych. Szerzej o problemach z zaopatrzeniem przed rozpoczęciem kampanii - vide M. KuKIEL, op. cit., t. I, s. 238-241.

${ }_{12}$ M. von Creveld, Żywiąc wojnę. Logistyka od Wallensteina do Pattona, Warszawa 2014, s. 88; A. Nieuważny, Nie liczyć na patriotyzm koni... Logistyczne dylematy Wielkiej Armii w 1812 r., http://ioh.pl/artykuly/pokaz/nie-liczy-na-patriotyzm-koni-logistyczne-dylematy-wielkiej-armiiw--r,1126/ [dostęp: 13 VIII 2019 r.]; A. ZAMOYsKI, op. cit., s. 191.

${ }_{13}$ P.B. Austin, 1812. Marsz na Moskwę, Gdańsk 2002, s. 68.

14 J.-R. Coignet, op. cit., s. 149; A. ZAmoyski, op. cit., s. 161-162. Przeciwne zdanie na temat wpływu burzy wyraził Ségur, według którego: „Burza [...] zatrwożyła nieliczne jednostki, ogół natomiast zachowywał się obojętnie”. P.P. DE SÉGUR, op. cit., s. 33. 
Według oficera Legii Nadwiślańskiej Henryka Brandta: „Każdy promyczek słońca witaliśmy z radością" 15 .

Kilkudniowa ulewa w znaczący sposób spowolniała również tempo marszu oddziałów Wielkiej Armii, co już po kilku dniach trwania działań wojennych stawiało pod znakiem zapytania możliwość powodzenia napoleońskiego planu kampanii zakładającego uderzenie na siły carskie w momencie ich rozproszenia oraz przecięcie im dróg odwrotu. Wymusiło to wykonywanie szybkich i dalekich marszów, które dały się we znaki żołnierzom jeszcze między Wisłą a Niemnem, zaś po przekroczeniu granicy rosyjskiej do kwestii problematycznych doszedł zły stan nieutwardzonych litewskich dróg, które w wyniku opadów zamieniały się w błoto, co utrudniało marsz zmęczonych żołnierzy i koni, a także powodowało jeszcze większą niewydolność systemu transportowego, gdyż stosowane przez Wielką Armię w 1812 r. ciężkie wozy taborowe nierzadko zapadały się po osie. Trudności z zaopatrzeniem - niewystarczająca wydolność batalionów pociągów, opóźnienie się żniw, zniszczenie części upraw przez gradobicia oraz przedwojenna polityka rosyjska, dążąca do rekwizycji nadwyżek żywności, doprowadziły do rozluźnienia się dyscypliny oraz skutkujących tym rabunków. Sabotowało to możliwość dokonywania, zamierzonych przez dowództwo napoleońskie, planowych rekwizycji, co jeszcze bardziej pogłębiało problemy z wyżywieniem wojsk. Według samego Napoleona nawet 50 tys. żołnierzy miało opuścić szeregi celem zdobycia żywności ${ }^{16}$. Upadek dyscypliny dotknął nawet oddziały polskie. Wedle słów Brandta: „Przykład dawany przez armię francuską zaczynał oddziaływać i na naszych ludzi; więzy karności nie rozpadły się jeszcze, ale stały się, że tak powiem, elastyczne"17.

Brak sprowokowania bitwy z wojskami rosyjskimi w okolicach Wilna nie sprawił, że Napoleon zrezygnował z próby doprowadzenia do jak najszybszego walnego starcia. Podobnie jak miało to miejsce przy okazji pierwszych dni kampanii, również i szanse na sukces planowanej operacji oparto w dużej mierze na założeniu szybkich przemarszów, co było niezwykle wyczerpujące dla żołnierzy. Sposób prowadzenia marszów w tym okresie następująco opisał oficer wojsk inżynierskich Księstwa Warszawskiego Klemens Kołaczkowski:

${ }^{15}$ H. Brandt, Moja służba w Legii Nadwiślańskiej, tłum. A. Bukowska, A. Zıó£коwsкi, Gdynia 2002, s. 170.

16 R. Andrzejewski, Kampania 1812 na Litwie - druga wojna polska, http://akant.org/archiwum/200-swiat-inflant/swiat-inflant-2017/swiat-inflant-2017-nr-10/6392-roman-andrzejewski-kampania-1812-na-litwie-druga-wojna-polska [dostęp: 26 IX 2019 r.]; R. BIELECKI, Napoleon, Warszawa 1979, s. 188; M. von Creveld, op. cit., s. 92-93; D. NAWrot, op. cit., s. 183-184.

${ }^{17}$ H. BRANDT, op. cit., s. 171. 
$\mathrm{Z}$ rana pobudka, po zakąsce chleba i wódki wojsko pod bronią stawało [...]. Czoło kolumn szło pośpiesznie, ostatnie plutony zadyszane doganiały; wśród marszu miały spoczynek, w czasie którego żołnierze jak niegdyś Gedeona, rzucali się do najbliższej wody dla ugaszenia pragnienia; potem dalej maszerowano aż do noclegu [...]. Dopieroż budowanie szałasów, rozpalanie ognisk, posyłki za wodą, żywnością, drzewem, tak że nawet w miesiącu czerwcu, gdzie dzień tak długi, żołnierz zgłodniały ledwie o godz. 10 wieczorem doczekał się straw ${ }^{18}$.

Poruszającym się w tym trybie żołnierzom dokuczał panujący szczególnie w lipcu i sierpniu upał, który żołnierze walczący w Hiszpanii i Egipcie porównywali do upałów panujących w tych państwach latem. Temperatury za dnia regularnie osiągały powyżej $30^{\circ} \mathrm{C}$, z kolei w nocy potrafiły one spaść do zaledwie kilku stopni Celsjusza, powodując hipotermię. Sytuacji nie polepszały pojawiające się cyklicznie opady deszczu (m.in. dość intensywna ulewa z 10 lipca). Warunki atmosferyczne dokuczały zarówno żołnierzom z Wielkiej Armii, jak i z wojsk rosyjskich. Długotrwałe występowanie wysokich temperatur powodowało wysychanie studni i strumieni, ograniczając i tak skąpe możliwości pozyskania wody pitnej. Zdesperowani żołnierze, w szczególności armii napoleońskiej, korzystali z każdej możliwości spożycia wody, w wyniku czego doszło do rozprzestrzenienia się wśród nich chorób, w tym dyzenterii. Trudne warunki przemarszów były dokuczliwe dla wszystkich rodzajów broni. W Wielkiej Armii szczególnie trudna sytuacja panowała w oddziałach kawalerii, co miało swoje źródło w sposobie sprawowania dowództwa przez komenderującego napoleońską kawalerią rezerwową króla Neapolu Joachima Murata, który nie liczył się z granicami wytrzymałości ludzi i koni, starając się działać jak najbardziej agresywnie w stosunku do Rosjan ${ }^{19}$.

Jeden z podkomendnych Murata, Julien Combe, opisał warunki maszerowania w miesiącach letnich:

Ciepło, w tym klimacie i o tej porze roku, nie jest ciepłem znanym w południowej Europie. Musieliśmy znosić nie tylko żar słońca, ale i jeszcze opary ze spieczonej ziemi. Nasze konie wznosiły chmurę piasku, która paliła się jak pył i którą byliśmy tak zakryci, że trudno byłoby rozróżnić kolorystykę naszych mundurów. Ten piasek, przenikając przez oczy, powodował okropny ból. Ledwo mogłem oddychać i pomimo palącego pragnienia wywołanego tymi okolicznościami, nie mogliśmy zatrzymać się, by się ochłodzić i zaspokoić pragnienie się w czystej wodzie kilku źródeł, które napotkaliśmy. Nasze konie, szczęśliwsze, zanurzały

${ }^{18}$ K. KoєАсzкоwsкi, Wspomnienia jenerała Klemensa Kołaczkowskiego. Księga I. od roku 1793 do 1813, Kraków 1898, s. 83-84.

19 P.B. Austin, op. cit., s. 349, 353; J. Czubaty, op. cit., s. 67; L.A. Picard, op. cit., s. 77; J. Tulard, Murat, Gdańsk 2002, s. 196-197; M.J. Turos, Dominique Jean Larrey (1766-1842). Chirurg Wielkiej Armii, Oświęcim 2017, s. 190; A. Zaмoyski, op. cit., s. 160, 177, 189-190. 
w nich swoje płonące nozdrza z pewną furią [...] nigdy nie doświadczyłem tak nieznośnego upału we Włoszech ${ }^{20}$.

Podobne odczucia miał również służący w piechocie Henryk Brandt, który zanotował ciekawą uwagę zwłaszcza w kontekście późniejszego odwrotu:

Pragnienie i kurz były naszem największym udręczeniem do chwili bitwy pod Możajskiem. [...] Ludzie niemal omdlewali z duchoty i brali do ust liście brzeziny, żeby stłumić pragnienie i zabezpieczyć się od kurzu. [...] Zimno, głód, deszcz, zła droga, nic tak nie męczy ludzi ${ }^{21}$.

Starający się zmusić Rosjan do bitwy Bonaparte, który, co warte odnotowania, sam w listach do żony dostrzegał panujące latem wysokie temperatury ${ }^{22}$, ponaglał swoich żołnierzy do większego wysiłku, czyniąc wyrzuty z powodu niewystarczającego tempa m.in. dowódcy polskiego V Korpusu, ks. Józefowi Poniatowskiemu, w wyniku czego: „ludzie padali z pragnienia lub umęczenia [...] książę Poniatowski zmartwiony wyrzutami cesarza, wspólnie z szefem sztabu Fiszerem pędził naszą piechotę, ażeby jak najprędzej dostać się do Dniepru"23.

Prowadzenie w opisany wyżej sposób marszy, w połączeniu z ich niesłabnącym tempem (niektóre oddziały potrafiły przejść $170 \mathrm{~km}$ w zaledwie 32 godziny) oraz panującymi upałami, skutkowało dalszym wykruszaniem się szeregów Wielkiej Armii - po jednym z wielu forsownych marszów w jednym z pułków westfalskich zostało jedynie 210 z 1980 żołnierzy. Choć część z tych strat marszowych nie miała charakteru permanentnego (maruderzy, ranni, chorzy), faktem pozostają znaczące ubytki w szeregach, do których swoją rękę przyłożyły również warunki pogodowe. Według danych przytaczanych przez Olega Sokołowa w okresie 25 czerwca-3 sierpnia polska 16 Dywizja Piechoty gen. Józefa Zajączka straciła 43,2\% stanu (4999 żołnierzy z 11 569), wirtemberska 25 Dywizja Piechoty gen. Jeana Marchanda - 49,9\% (3984 z 7991), zaś włoska 15 Dywizja Piechoty gen. Domenico Pinota - 53,5\% (6456 z 12 069). Znaczne mniejsze stany miały również wielkie jednostki kawalerii - 1 Dywizja Kirasjerów gen. Antoine’a de Saint-Germaina między 25 czerwca a 23 sierpnia zmalała o 54,7\% (z 3111 do 1404 żołnierzy). Straty nie ominęły również wojsk rosyjskich, które także ponosiły ofiary spowodowane forsownymi marszami w trudnych warunkach atmosferycznych oraz

${ }^{20}$ J. Combe, Memoires du colonel Combe sur les campagnes de Russie, 1812, de Saxe 1813, et de France 1814 et 1815, Paris 1853, s. 74-75.

${ }^{21}$ H. BRANDT, op. cit., s. 185-186.

${ }^{22}$ M.in. w liście z 24 VIII pisał: „Zdaje mi się, że w Paryżu nie jest tak gorąco jak tutaj. Mamy dzisiaj 26 stopni [Réaumura, $32,5^{\circ} \mathrm{C}$ ); już od miesiąca trwa taka pogoda”. Listy Napoleon do Marji-Ludwiki, red. Ch. De La Ronciere, Warszawa 1936, s. 79.

${ }^{23}$ K. KoŁACzKowski, op. cit., s. 99. 
niewydolnością systemu zaopatrzenia, choć nie miały one skali takiej jak w armii napoleońskiej ${ }^{24}$. Dość osobliwego, lecz oddającego stan rzeczy, porównania stanu obu wojsk dokonał jeden z lekarzy służących w Wielkiej Armii - Heinrich von Roos:

ekskrementy pozostawione przez ludzi i zwierzęta za frontem rosyjskim wskazywały na ich dobry stan zdrowia, podczas gdy za naszymi oddziałami znajdywaliśmy wszelkie możliwe i całkiem wyraźne oznaki, że cała armia, zarówno ludzie, jak i konie, musiała cierpieć z powodu rozwolnienia ${ }^{25}$.

Ostatecznie, mając na uwadze stan swoich oddziałów oraz odwrót Rosjan na Smoleńsk, Bonaparte zdecydował się na postój w Witebsku, po którym przystąpił do realizacji manewru smoleńskiego, gdzie znów narzucił wysokie tempo, co widoczne było w przytoczonej wyżej wypowiedzi K. Kołaczkowskiego ${ }^{26}$. Nie bez przyczyny, wspominając postój w Witebsku, wielki koniuszy cesarza Francuzów Armand de Caulaincourt stwierdził, że: „największym szczęściem dla armii była możliwość wypoczynku"27.

Jak już wspomniano, najbardziej znanym i najszerzej omawianym wpływem warunków pogodowych na przebieg kampanii był destrukcyjny wpływ rosyjskiej zimy na wycofującą się z Moskwy Wielką Armię. Obrazując to zagadnienie, szczególnie w sztuce, najczęściej przedstawia się maszerujących przez zaśnieżone pola żołnierzy napoleońskich. Tymczasem wpływ warunków pogodowych w miesiącach jesienno-zimowych, w szczególności podczas pierwszego etapu odwrotu (do bitwy nad Berezyną), był znacznie bardziej złożony. Uznany francuski badacz epoki napoleońskiej Jean Tulard posunął się nawet do postawienia tezy, że w okresie od wyjścia wojsk napoleońskich z Moskwy do bitwy nad Berezyną (okres $25 \mathrm{dni}$ ) jedynie przez trzy dni panowały mrozy, a mimo to armia Bonapartego miała utracić około 65 tys. żołnierzy, zarówno w wyniku strat bojowych (bitwy pod Małojarosławcem i Krasnym, ataki kozaków), jak i niebojowych; dopiero w drugim etapie odwrotu temperatura poniżej zera stopni Celsjusza miała panować nieprzerwanie przez $22 \mathrm{dni}^{28}$.

Przyjęcie za możliwą do zaakceptowania tezy francuskiego badacza nie oznacza, że warunki pogodowe nie wpływały w tym okresie na przebieg toczącej się kampanii. Faktem jest, że jeszcze w połowie października temperatura, jak na standardy rosyjskie, była dość wysoka. Chociażby A. de Caulaincourt podaje

${ }^{24}$ O. SokoŁow, Armia Napoleona, Oświęcim 2014, s. 248; A. ZАмоуsкi, op. cit., s. 184, 190, 237.

${ }^{25}$ P.B. Austin, op. cit., s. 260-261.

${ }^{26}$ M. Kukiel, op. cit., t. I, s. 301; D. Nawrot, op. cit., s. 185; P.P. de SÉGUr, op. cit., s. 46-47.

27 A. DE Caulaincourt, Wspomnienia z wyprawy na Moskwę 1812 r., tłum. I. Łygaś, Gdańsk 2006, s. 122.

${ }^{28}$ J. Tulard, Napoleon - mit zbawcy, Warszawa 2003, s. 441. 
następujący komentarz Napoleona z tego okresu: „Pogoda jest wspaniała - co do klimatu byliśmy w błędzie, a jesień jest tu piękniejsza niż w Fontainbleau”29. Sytuacja zaczęła zmieniać się po ewakuacji Moskwy, kiedy to pogoda przybrała bardziej deszczowy charakter. Podobnie jak miało to miejsce latem na Litwie, także i w tym przypadku doszło do znacznego pogorszenia się stanu dróg. Miało to istotne znaczenie, szczególnie w momencie podjęcia przez Napoleona decyzji o przerwaniu manewru ofensywnego na Kaługę i powrotu na trakt smoleński wobec znacznej ilości taborów, nierzadko przewożących łupy zdobyte w Moskwie, ale także rannych zabranych z moskiewskich szpitali, których zawczasu nie ewakuowano ${ }^{30}$.

Przechodząc do casusu mrozu, przy analizie tego problemu trzeba zaznaczyć, że zarówno wśród samych pamiętnikarzy, jak i historyków panuje niezgodność co do tego, kiedy temperatury ujemne zaczęły pojawiać się w sposób regularny. Według danych meteorologicznych $\mathrm{z}$ obserwatorium astronomicznego w Wilnie, przytaczanych przez Olega Sokołowa, w okresie 28 października-28 listopada było aż 20 dni $\mathrm{z}$ temperaturą niższą niż $0^{\circ} \mathrm{C}$, choć nigdy nie spadała ona poniżej $-10^{\circ} \mathrm{C}$, co z kolei kłóci się z przekazami źródłowymi. Można to jednak po części zrozumieć, mając na uwadze fakt znajdowania się armii na wschód od stacji pomiaru ${ }^{31}$. Najwcześniejszą datę $e^{32}$ pojawienia się mrozów, 12 października, podaje w swojej biografii Napoleona Robert Bielecki, powołując się zapewne na K. Kołaczkowskiego ${ }^{33}$. Według Mariana Kukiela miało to miejsce w nocy 28/29 października ${ }^{34}$, Franciszek Gajewski w swoich wspomnieniach pisze, iż: „Mróz chwycił nagle i bez jakiegokolwiek wstępu doszedł od razu do 15 stopni Réaumura $\left[-18.75^{\circ} \mathrm{C}\right]^{33}$, zaś J.-R. Coignet początek zimy datuje na 6 listopada ${ }^{36}$.

Mając na uwadze stan pogody w październiku, szczególnie w pierwszej części tego miesiąca, nadejście pierwszych mrozów było dla napoleońskiego dowództwa, ale także samych żołnierzy zaskoczeniem, co zresztą przyznał w swoich wspomnieniach sam Bonaparte ${ }^{37}$. Warto w tym miejscu wspomnieć, że ani cesarz,

${ }^{29}$ A. DE CAulaincourt, op. cit., s. 207.

${ }^{30}$ Generat Mróz?; M. KuKIEL, op. cit., t. II, s. 331; P.P. DE SÉGUR, op. cit., s. 195.

${ }^{31}$ O. Soкоєоw, op. cit., s. 298.

${ }^{32}$ Pojawienie się pierwszego śniegu można datować jeszcze wcześniej, gdyż według wspomnień Henryka Dembińskiego miało do tego dojść w noc po bitwie pod Czirikowem, mianowicie 29/30 IX. H. Dembiński, Pamiętnik Henryka Dembińskiego jenerała wojsk polskich, Poznań 1860, s. 154.

${ }^{33}$ R. Bielecki, op. cit., s. 196; K. KoŁACZKowsKi, op. cit., s. 146.

${ }^{34}$ M. Kuniel, op. cit., t. II, s. 334.

${ }^{35}$ F. Gajewski, Pamiętniki Franciszka z Błociszewa Gajewskiego do druku przysposobione przez prof. dra Stanisława Karwowskiego, t. I, Poznań 1913, s. 263.

${ }^{36}$ J.-R. CoIGneT, op. cit., s. 165.

${ }^{37}$ „7 listopada niespodziewanie [wytłuszczenie - D.G.] zrobiło się zimno”. Wspomnienia Napoleona, Tom 8, https://napoleon.org.pl/index.php/biblioteka-empire-u/czytelnia/zrodla/wspomnienia-napoleona/193-wspomnienia-napoleona-tom-8 [dostęp: 15 VIII 2019 r.]. 
ani też żaden z jego dowódców w siłach głównych nie podjął inicjatywy wszczęcia systemowych przygotowań do działań w warunkach zimowych, co zresztą w swoich wspomnieniach P. de Ségur wypomina szefowi sztabu Wielkiej Armii - marszałkowi Louisowi-Alexandre'owi Berthierowi ${ }^{38}$.

Przyjmując nawet możliwie krótki okres trwania mrozów w pierwszym okresie odwrotu, był on niezwykle groźny dla żołnierzy z dwóch powodów. Po pierwsze, wojska napoleońskie dysponowały ograniczonymi zapasami żywności, co wobec forsowności marszów doprowadzało do znacznego zwiększenia się liczby maruderów rekrutujących się głównie spośród żołnierzy, których dyscyplina i morale znacząco upadły podczas pobytu w Moskwie. Zresztą wielu żołnierzy wolało zabrać ze sobą w drogę łupy niż większe zapasy jedzenia, co okazało się niezwykle zgubne. Obrazują to słowa F. Gajewskiego: „W pierwszym i drugim etapie wojsko się trzymało jako tako, ale trzeciego dnia rzuciło kilka tysięcy broń, a każdy pobiegł za żywnością i odzieżą według instynktu"39. Po drugie, zarówno żołnierze, jak i konie nie byli przygotowani ani przystosowani do maszerowania $\mathrm{w}$ warunkach zimowych pod względem posiadania właściwych umiejętności/praktyki, a także przygotowania pod kątem odzieży oraz pokucia w przypadku koni. Szczególnie w pierwszym okresie odwrotu, podczas występujących na przemian mrozów i odwilży, pojawiała się gołoledź, co powodowało trudności z pokonywaniem wzniesień. Jedynie polscy żołnierze, mając odpowiednią wiedzę o sytuacji w Rosji zimą, podkuli swoje konie na ostro, dzięki czemu chociażby w przeciwieństwie do Francuzów nie musieli porzucać dział, a ich konie nie traciły życia w wyniku połamania nóg na śliskich drogach ${ }^{40}$. Jak wspominał P. de Ségur: „konie, jak ludzie dyszeli wtedy ostatkiem tchu, przewracając się co chwila"t1.

Odnośnie do przygotowania żołnierzy pod względem odzieży temat w wyczerpujący sposób przedstawił Henryk Brandt:

Każdy wieśniak potrafiłby lepiej sobie poradzić. Żołnierze, zamiast osłaniać szyje, twarze i uszy, owijali nogi masą gałganów i chustek, co naturalnie utrudniało chód. Często wiązali chustki na piersiach, tam gdzie najmniej było potrzebne,

${ }^{38}$ P.P. DE SÉGUR, op. cit., s. 190-191. Warto wspomnieć, że tego rodzaju działania podjęto za to w operującym na terenie Kurlandii X Korpusie, którego dowódca, marszałek Étienne Macdonald, zarządził przeprowadzenie rekwizycji ciepłej odzieży, dzięki czemu w tym korpusie, znajdującym się także w lepszej sytuacji pod względem zaopatrzenia, ograniczono straty niebojowe. D. GrALIK, Działania polskich pułków dywizji gdańskiej w okresie odwrotu Wielkiej Armii z Rosji (październik 1812 - styczeń 1813), https://www.infolotnicze.pl/2018/12/27/dzialania-polskich-pulkow-dywizjigdanskiej-w-okresie-odwrotu-wielkiej-armii-z-rosji-pazdziernik-1812-styczen-1813/ [dostęp: 3 IX 2019 r.].

${ }^{39}$ F. GajewsKi, op. cit., s. 263-264.

${ }^{40}$ H. Brandt, op. cit., s. 242; K. Ko€aczKowsKi, op. cit., s. 154.

${ }^{41}$ P.P. DE SÉGUR, op. cit., s. 229. 
zamiast chronić nimi nosy i uszy przed odmrożeniem. [...] Nic zatem dziwnego, że padali tłumnie ofiarą $\mathrm{mrozu}^{42}$.

Żołnierze napoleońscy mieli również problem z nocowaniem pod gołym niebem, co było często koniecznością, gdyż rzadko zaludniona Rosja (dodatkowo na tym obszarze zniszczona wcześniejszymi działaniami wojennymi) ograniczała możliwość kwaterowania oddziałów. Problem tego typu występował nawet w Smoleńsku, który jednakże był zrujnowany w wyniku bitwy z połowy sierpnia $^{43}$. W efekcie pojawiały się przypadki podpalania domostw przez żołnierzy, którzy nie mogli znaleźć $\mathrm{w}$ nich schronienia z powodu przepełnienia. Jeszcze bardziej ograniczało to bazę noclegową, przede wszystkim dla żołnierzy nieznajdujących się w awangardzie maszerujących wojsk ${ }^{44}$.

Biwakujący pod raz pierwszy na mrozie pod gołym niebem żołnierze nie wiedzieli też chociażby o konieczności stałego podtrzymywania ognia, w wyniku czego wielu $\mathrm{z}$ nich zmarło w pierwszych dniach panowania mrozów. Jak celnie zauważył kapitan 1 pułku szwoleżerów-lansjerów Gwardii Cesarskiej (polskiego) Józef Załuski:

Zdaje się, że 22 stopni mrozu dla biwakujących, głodnych, źle odzianych i niedbałych o siebie jest zimnem zabójczym, ale nie jest takim, żeby przy zachowanych przezornościach nie móc odbywać zimowej kampanii45

Niewłaściwe odzienie oraz złe korzystanie z ognisk prowadziło do pojawienia się plagi odmrożeń. Trzeba tutaj zaznaczyć, że nawet wiedza medyczna lekarzy na ten temat była dość ograniczona - po raz pierwszy szerzej temat ten został omówiony przez naczelnego chirurga Wielkiej Armii Dominique’a Jeana Larreya $\mathrm{w}$ jego wspomnieniach wydanych tuż przed początkiem wyprawy, gdzie analizował doświadczenia z kampanii zimowej w Prusach Wschodnich z zimy 1806/1807 r. oraz kampanii w Hiszpanii z 1808 r. ${ }^{46}$

Drugi okres odwrotu (po bitwie nad Berezyną) przyniósł mrozy, które same w sobie były już zabójcze. 30 listopada w Pleszczenicach odnotowano $-30^{\circ} \mathrm{C}$, w Miednikach 6 grudnia zapisano $-37,5^{\circ} \mathrm{C}$, zaś w nocy $7 / 8$ grudnia temperatura miała spaść aż do $-44^{\circ} \mathrm{C}^{47}$. W kolejnych dniach temperatura sięgała $-35^{\circ} \mathrm{C}$.

${ }^{42}$ H. BRANDT, op. cit., s. 255.

${ }^{43}$ Jak wspominał Christian Wilhelm von Faber du Faur: „Biwak w głębokim śniegu, w ruinach lub na podwórku wypalonego domu, kilka nędznych wiktuałów [...] to było wszystko, co znaleźliśmy w Smoleńsku". Cyt. za: A. ZAmoyski, op. cit., s. 412.

${ }^{44}$ R. BieleCKI, op. cit., s. 202.

${ }^{45}$ J. ZaŁuski, Wspomnienia, Kraków 1976, s. 256.

${ }^{46}$ M.J. Turos, op. cit., s. 181; A. ZAmoyski, op. cit., s. 441.

${ }^{47}$ Co ciekawe, w swoich wspomnieniach J. Załuski podaje w wątpliwość możliwość występowania tak niskich temperatur, powołując się na swoje wcześniejsze doświadczenia. J. ZAŁUsKi, op. cit., s. 256. 
Temperatura na tym poziomie doprowadziła do znacznego ograniczenia skali działań. Jak wspominał H. Brandt:

Cała okolica, lasy, domy, pola pokryte były śniegiem, którego białość oślepiała oczy. Słońce świeciło jak ognista kula, ale nie grzało wcale. Igiełki lodowe wirowały w powietrzu, iskrząc się na kształt brylantów i kłując boleśnie w oczy ${ }^{48}$.

Z kolei, według A. de Caulaincourta:

Panował tak silny mróz, że pozostawanie pod gołym niebem było wręcz nie do wytrzymania. [...] Na każdym kroku można było spotkać ludzi z odmrożeniami, którzy nagle zatrzymywali się, po czym padali z powodu osłabienia ${ }^{49}$.

Bardzo niska temperatura czyniła broń palną bezużyteczną, gdyż karabiny przymarzały do palców, pod wpływem zimna łamliwe stawały się kolby oraz lufy karabinów. Wpływ tych ekstremalnych warunków pogodowych na stan wojsk pokazuje przykład posiłkowego pułku wirtemberskiego, który dołączył do armii 5 grudnia w Smorgoniach w sile 1360 ludzi, zaś cztery dni później w Wilnie odnotowano jedynie 60 żołnierzy tego regimentu. Podobnie rzecz miała się z jednostkami zbliżającego się na teren działań wojennych XI Korpusu ${ }^{50}$.

Warunki pogodowe podczas odwrotu wpływały także na znaczne straty w szeregach armii rosyjskiej. Mimo lepszego niż w przypadku żołnierzy napoleońskich przygotowania pod względem posiadanej odzieży, a także znanej wytrzymałości rosyjskiego żołnierza ${ }^{51}$, również i poddani cara padali ofiarą zimy. Działo się to tym bardziej, że znaczny procent podkomendnych rosyjskiego naczelnego wodza, marszałka Michaiła Kutuzowa, stanowili rekruci, którzy dołączyli do armii podczas jej reorganizacji w obozie pod Tarutino. Ponadto, po okresie dość dobrego zaopatrzenia w obozie, również armia carska zaczęła mieć problemy z pozyskaniem zaopatrzenia tym bardziej, że Rosjanie poruszali się na zniszczonym wojną obszarze, do tego $\mathrm{w}$ roli ścigających przeciwnika. Przykładem ilustrującym tragiczny niekiedy los żołnierzy rosyjskich podczas ich kontrofensywy są dzieje pomocniczego pułku piechoty sformowanego w Tule, którego pierwszy batalion wyginął prawie całkowicie z powodu zimna, co spowodowało bunt pozostałych przy życiu żołnierzy ${ }^{52}$.

${ }^{48}$ H. BrandT, op. cit., s. 257.

49 A. De Caulaincourt, op. cit., s. 329.

${ }^{50}$ J.-R. Coignet, op. cit., s. 169; M.J. Turos, op. cit., s. 198; A. ZAmoyski, op. cit., s. 476, 491, 498.

${ }^{51}$ Co roku, z powodu złych warunków bytowych, umierało nawet $25 \%$ żołnierzy rosyjskich. W. Biezotosny, Żotnierska dola. Zaopatrzenie rosyjskiego żołnierza w 1812 roku, „Mówią Wieki. Ów roku 1812" 2002, nr specjalny, s. 61.

${ }^{52}$ Generał Mróz?; W. Biezotosny, op. cit., s. 62 
Skalę strat w wojsku rosyjskim obrazują też liczby. W głównej armii M. Kutuzowa spośród 120 tys. ludzi i 622 dział, które wyruszyły z obozu tarutińskiego, do Niemna doszło zaledwie 40 tys. żołnierzy i 200 dział ${ }^{53}$. Armia Dunajska adm. Pawła Cziczagowa zmniejszyła się z 40 tys. do 24,5 tys. ludzi, zaś w zgrupowaniu gen. Piotra Wittgensteina $\mathrm{z}$ wyjściowych 50 tys. ostało się 34,5 tys. ${ }^{54}$

Na zakończenie niniejszego tekstu warto pochylić się nad próbą ogólnej oceny wpływu wszystkich przedstawionych przykładów na działania zbrojne toczone w 1812 r. Przede wszystkim należy zauważyć, że, może poza drugą fazą odwrotu Wielkiej Armii, gdzie warunki atmosferyczne miały charakter zgoła ekstremalny, w żadnym przypadku pogoda nie była głównym czynnikiem determinującym przebieg działań wojennych. Jednak uwydatniała oraz wzmacniała inne czynniki, tak jak miało to miejsce chociażby latem, gdy burza z przełomu czerwca i lipca jedynie przyspieszyła proces masowego padania koni, zaś upały z lipca i sierpnia były katalizatorem znacznych strat marszowych. Adam Zamoyski, odnosząc się do przyczyn takiego, a nie innego wyniku odwrotu stwierdził, iż: „I choć mróz mógł nie stanowić podstawowej, a nawet głównej przyczyny katastrofy, to ostatecznie udaremnił wszelkie próby zminimalizowania szkód"55. W podobnym duchu wypowiedział się na łamach swojej pracy M. Kukiel, który przyczyny katastrofy Wielkiej Armii widział w aspektach stricte militarnych (działania Cziczagowa i Wittgensteina na flankach wojsk napoleońskich), lecz celnie zauważył, że klimat Rosji, wraz z jej ogromnym terytorium oraz strategią Rosjan, osłabiał „technikę operacyjną" Napoleona, wymuszając na nim wiele trudnych decyzji ${ }^{56}$.

Zwłaszcza w kontekście zimy warto też poczynić porównanie z kampanią w Prusach Wschodnich z przełomu 1806/1807 r. Tam też wojska francuskie operowały w niesprzyjającym sobie terenie i klimacie, jednakże dzięki przejściu na leża zimowe (chwilowo przerwane przez ofensywę prusko-rosyjską), bliskości zaplecza (przyjazne ziemie polskie) oraz wysokiej dyscyplinie udało się, i to pomimo sporych strat ${ }^{57}$, dotrwać do wiosny i przeprowadzić zwycięską ofensywę zwieńczoną efektownym zwycięstwem pod Frydlandem. Na to porównanie zwracają zresztą uwagę pamiętnikarze, np. H. Brandt ${ }^{58}$.

Na marginesie tych rozważań warto zauważyć, że wpływ na postrzeganie roli warunków pogodowych, tj. mniemanie o ich decydującej roli, mogła mieć napoleońska propaganda, która już w trakcie samej kampanii forsowała tezę

${ }^{53}$ Tylko do końca bitwy pod Krasnym (18 listopada) Kutuzow stracił 30 tys. ludzi zabitych i rannych, drugie tyle zostało maruderami. A. Zamoyski, op. cit., s. 428-429.

${ }^{54}$ A. NieuważNy, Kampania 1813 r. na pótnocnym zachodzie Księstwa Warszawskiego. Napoleońska twierdza Toruń i jej obrona, Toruń 2017, s. 37.

${ }_{55}$ A. ZAmoyski, op. cit., s. 516-517.

56 M. KuKIEL, op. cit., t. II, s. 512-514.

${ }^{57} 31$ I 1807 r. w korpusach Wielkiej Armii znajdowało się około 86 tys. ludzi, podczas gdy 7 II - tylko 64 tys. T. Rogacki, Pruska Iława 1807, Warszawa 2004, s. 101.

${ }^{58}$ H. BRANDT, op. cit., s. 264 
o nadrzędnej roli mrozów w destrukcji wojsk napoleońskich. Wątek ten pojawił się po raz pierwszy w 28 biuletynie Wielkiej Armii datowanym na 11 listopa$\mathrm{da}^{59}$. Motyw wpływu zimna został rozbudowany w słynnym 29 biuletynie, który miał przekazać społeczeństwu francuskiemu przyczyny klęski w Rosji. Możemy w nim przeczytać m.in.:

Do 6 listopada ${ }^{60}$ pogoda była idealna, a ruch wojsk był wykonywany z największym powodzeniem. Zimno zaczęło się siódmego, od tej chwili każdej nocy straciliśmy kilkaset koni, które umierały na biwaku. Zanim dotarliśmy do Smoleńska, straciliśmy większość koni kawalerii i artylerii. [...] Mróz, który zaczął się siódmego, szybko rósł i w nocy z 14 na 15 oraz 16 listopada termometr pokazywał 18 stopni poniżej zera [Réaumura tj. $-22,5$ st. C]. Drogi pokryte były lodem; konie kawalerii, artylerii i pociągów padały nie setkami, ale tysiącami - przede wszystkim te z Francji i Niemiec. W krótkim czasie zginęło ponad trzydzieści tysięcy koni. Nasza jazda została bez wierzchowców, nasza artyleria i transport znajdowały się bez siły pociągowej. Trzeba było porzucić i zniszczyć większość naszych dział i amunicji. Ta armia - tak piękna 6 listopada - 14 listopada była już całkiem inna. Prawie żadnej kawalerii, żadnej artylerii, bez transportu. [...] Trudności te, połączone z rosnącym mrozem, uczyniły naszą sytuację niekorzystną ${ }^{61}$.

Nawet po swoim upadku Bonaparte dalej optował za wyjątkową rolą "generała Mroza" w pokonaniu jego wojsk w 1812 r. Chociażby w słynnym Memoriale ze Świętej Heleny były już wtedy cesarz Francuzów stwierdził, iż:

Gdyby tęgie mrozy nie nastąpiły dwa tygodnie wcześniej niż zazwyczaj, armia francuska po pożarze Moskwy dotarłaby bez strat do Smoleńska [...]. Wiedziano, iż w Rosji panują mrozy w grudniu i styczniu, ale porównując temperatury z ostatnich dwudziestu lat, można było przypuszczać, że w listopadzie temperatura nie przekroczy minus dziesięciu stopni ${ }^{62}$.

Podobnie wypowiedział się w swoich wspomnieniach:

Gdyby natura nie była przeciwko cesarzowi, wszystko skończyłoby się szczęśliwie. [...] Gdyby ten straszliwy mróz nastał przynajmniej 3 dni później, odwrót odbyłby się w całkowitym porządku ${ }^{63}$.

${ }^{59}$ J.-O. Boudon, Biuletyny Wielkiej Armii - narzędzie propagandy, „Mówią Wieki. Ów roku 1812” 2002, nr specjalny, s. 95; Les Bulletins de la Grande Armée précédés des rapports sur l'armée française, depuis Toulon jusqu'à Waterloo, extraits textuellement du Moniteur et des Annales de l'empire, ed. A. PASCAL, t. V, Paris 1844, s. 325-326.

${ }^{60}$ W cytowanej edycji błędnie podano grudzień jako nazwę miesiąca.

${ }^{61}$ Le Bulletins..., s. 329-330.

${ }^{62}$ E. De Las Cases, Memoriał ze Świętej Heleny, t. III, tłum. J. Kortas, Gdańsk 2012, s. 93.

${ }^{63}$ Wspomnienia..., https://napoleon.org.pl/index.php/biblioteka-empire-u/czytelnia/zrodla/wspomnienia-napoleona/193-wspomnienia-napoleona-tom-8 [dostęp: 15 VIII 2019 r.]. 
Narrację stworzoną przez Napoleona została podchwycona w części pamiętników - m.in. P. de Ségura ${ }^{64}$.

Podsumowując, można sformułować uogólniające stwierdzenie. Warunki pogodowe wpływały na przebieg kampanii rosyjskiej w ciągu całości jej trwania. Nie tylko negatywną rolę odegrały niskie temperatury w późniejszym okresie kampanii. Choć zazwyczaj nie miały one znaczenia decydującego, z pewnością wywarły istotny wpływ na działania zbrojne obu stron konfliktu.

\section{Dawid Gralik}

\section{NOT JUST „GENERAL FROST”. THE INFLUENCE OF WEATHER FACTORS ON THE COURSE OF NAPOLEON'S RUSSIAN CAMPAIGN ON SELECTED EXAMPLES}

Summary: Napoleon's Russian campaigns one of the best known examples of the impact of weather conditions on the process of military actions. In the article, on selected examples, the influence of weather on the actions and condition of both armies, mainly the Great Army, is analyzed. Adverse weather conditions accompanied the 1812 warfare from the very beginning in the form of a storm that took place at the turn of June and July. Then a period of intense heat began, which caused considerable problems for the soldiers moving in fast marches, who were also deprived of access to drinking water. Finally, the extremely cold winter, even for Russia's climate, contributed, however not always directly, to deaths of many soldiers on both sides of conflict. Although weather is difficult to see as the main cause of Napoleon's defeat, it was an extremely important part of 1812 military actions.

Keywords: 1812, Russian campaign, Napoleon Bonaparte, war and weather, Napoleonic Wars.

64 P.P. DE SÉGUR, op. cit., s. 389. 